\title{
Intrapreneurial Self-Capital, Kecerdasan Emosional dan Self-Perceived Employability pada Mahasiswa Tingkat Akhir
}

\author{
FIQI HARIYA AFSHIDA \& CHOLICHUL HADI* \\ Departemen Psikologi Industri dan Organisasi, Fakultas Psikologi Universitas Airlangga
}

\begin{abstract}
ABSTRAK
Penelitian ini bertujuan untuk mengetahui apakah terdapat hubungan antara intrapreneurial selfcapital dan kecerdasan emosional terhadap self-perceived employability pada mahasiswa tingkat akhir. Penelitian ini dilakukan pada mahasiswa tingkat akhir dengan jumlah partisipan sebanyak 327 orang, baik dari program sarjana ataupun diploma. Data diperoleh menggunakan metode survei dan teknik pengambilan sampel berupa accidental sampling. Alat pengambilan data berupa Intrapreneurial SelfCapital Scale, skala Trait Emotional Questionnaire Short-Form dan Self-Perceived Employability Scale. Analisis data yang digunakan adalah uji korelasi sederhana. Hasil dari penelitian ini diketahui bahwa terdapat hubungan yang positif dan moderat antara intrapreneurial self-capital dan kecerdasan emosional terhadap self-perceived employability.
\end{abstract}

Kata kunci: intrapreneurial self-capital, kecerdasan emosional, mahasiswa tingkat akhir, self-perceived employability

\begin{abstract}
This study aims to determine whether there is a relationship between intrapreneurial self-capital and emotional intelligence on self-perceived employability in final year students. This research was conducted on final year students with a total of 327 participants, both from undergraduate and diploma programs. The data was obtained using a survey method and sampling technique in the form of accidental sampling. Data collection tools are Intrapreneurial Self-Capital Scale, Trait Emotional Questionnaire Short-Form scale and Self-Perceived Employability Scale. Analysis of the data used is a simple correlation test. The results of this study indicated that there is a positive and moderate relationship between intrapreneurial self-capital and emotional intelligence on self-perceived employability.
\end{abstract}

Keywords: emotional intelligence, final-year student, intrapreneurial self-capital, self-perceived employability

INSAN Jurnal Psikologi dan Kesehatan Mental, tahun, Vol. 6(1), 70-78, doi: 10.20473/jpkm.v6i12021.70-78

Dikirimkan: 16 Desember 2016 Diterima: 7 Juli 2021 Diterbitkan: 12 Juli 2021

Editor: Rizqy Amelia Zein

*Alamat korespondensi: Fakultas Psikologi Universitas Airlangga, Kampus B Universitas Airlangga Jalan Airlangga 4-6 Surabaya 60286. Surel: cholichul.hadi@psikologi.unair.ac.id

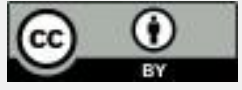

Naskah ini merupakan naskah dengan akses terbuka dibawah ketentuan the Creative Common Attribution License (http://creativecommons.org/licenses/by/4.0), sehingga penggunaan, distribusi, reproduksi dalam media apapun atas artikel ini tidak dibatasi, selama sumber aslinya disitir dengan baik. 


\section{P E N D A H U L U A N}

Motivasi seseorang untuk memasuki dunia pendidikan tinggi pada umumnya dianggap sebagai proses belajar secara spesifik dan mendalam untuk mendapatkan gelar dengan harapan dapat menemukan pekerjaan yang lebih baik (Potgieter \& Coetzee, 2013). Hal tersebut dikarenakan seringkali terdapat persepsi di masyarakat bahwa semakin tinggi pendidikan yang dimiliki oleh seseorang, maka akan semakin mudah untuk menemukan dan mendapatkan pekerjaan. Gelar pengetahuan, pemahaman, dan keterampilan dianggap sebagai elemen utama dan penting bagi perusahaan atau para pencari karyawan (Potgieter \& Coetzee, 2013) sehingga seringkali para pencari karyawan atau employers mengharapkan universitas dan lembaga pendidikan tinggi lainnya untuk menghasilkan siswa dan lulusan yang dapat dipekerjaan serta memiliki keterampilan yang relevan (Coetzee, 2012).

Indonesia menempati peringkat ketiga sebagai negara pertumbuhan lulusan universitas lebih dari 4 persen dan rata-rata surplus 1,5 persen per tahun setelah negara India dan Brazil (Gewati, 2018). Menteri Ketenagakerjaan (Menaker), M. Hanif Dhakiri menyatakan bahwa angkatan kerja baru (AKB) mencapai 750.000 sampai dengan 800.000 lulusan perguruan tinggi, akan tetapi banyaknya AKB tersebut tidak bisa langsung masuk ke pasar tenaga kerja walaupun dunia industri menginginkan pekerja yang bisa siap pakai (Raharjo, 2017). Kurang siapnya lulusan perguruan tinggi secara tidak langsung berdampak pada sulitnya perusahaan untuk memperoleh lulusan yang dapat dipekerjakan. Hal tersebut juga didukung dengan hasil survei dari Willis Towers Watson tentang Talent Management and Rewards yang dilakukan sejak tahun 2014 hingga tahun 2016, yang menyebutkan bahwa delapan dari sepuluh perusahaan di Indonesia kesulitan untuk mendapatkan lulusan perguruan tinggi dalam negeri siap pakai (Gewati, 2016).

Begitu pula dengan sensus ekonomi yang dilakukan oleh Badan Pusat Statistik (BPS) pada tahun 2016 menunjukkan bahwa jumlah perusahaan yang ada di Indonesia sebanyak 26,7 juta yang mana jumlah tersebut meningkat dibandingkan dengan sensus ekonomi pada tahun 2006 yakni sebanyak 22,7 juta perusahaan (Agustinus, 2016). Dari data tersebut diketahui bahwa dalam kurun waktu 10 tahun terakhir, jumlah perusahaan baru di Indonesia meningkat sekitar 3,98 juta, namun banyaknya perusahaan tersebut tidak sebanding dengan tenaga kerja yang dibutuhkan oleh perusahaan (Agustinus, 2016). Hal tersebut juga didukung dengan riset yang telah dilakukan oleh Asia-Pacific Economic Cooperation (APEC) pada tahun 2015 yang menunjukkan bahwa sebenarnya Indonesia tidak kekurangan lulusan atau sarjana, tetapi kekurangan pekerja yang terampil (Iredale, dkk., 2015).

Di sisi lain, banyaknya lulusan setiap tahun dari berbagai universitas juga menyebabkan semakin meningkatnya persaingan di dunia kerja sehingga menimbulkan masalah pengangguran. Direktur Jenderal Pembelajaran dan Kemahasiswaan Kementerian Teknologi dan Pendidikan Tinggi, Intan Ahmad mengatakan bahwa terdapat ratusan ribu lulusan perguruan tinggi yang menganggur setiap tahunnya. Lulusan perguruan tinggi dalam satu tahun bisa mencapai hingga satu juta jiwa sedangkan yang menganggur mencapai ratusan ribu (Indriani, 2018). Hal tersebut didukung dengan data dari Badan Pusat Statistik pada tahun 2018, bahwa tingkat pengangguran lulusan universitas naik sebesar 1,13 persen, dari 5,18 persen menjadi 6,31 persen dan untuk pengangguran lulusan diploma I/II/III juga naik sebesar 1,04 persen, dari 6,88 persen menjadi 7,92 persen sehingga dari data tersebut diketahui bahwa terdapat penawaran tenaga kerja yang tidak terserap sepenuhnya (Badan Pusat Statistik, 2018).

Secara keseluruhan, Tingkat Pengangguran Terbuka (TPT) di Indonesia mencapai 5,13 persen atau setara dengan 6.000 .000 orang. Tingkat pengangguran di Indonesia menempati urutan pertama di Asia Tenggara yaitu sebesar 5,34 persen, disusul dengan Filipina sebesar 5,20 persen, Malaysia sebesar 3,2 persen, Singapura sebesar 2,20 persen, Vietnam sebesar 2,18 persen, Thailand dan Myanmar sebesar 0,80 persen, dan Laos sebesar 0,68 persen (Kevin, 2019).

INSAN Jurnal Psikologi dan Kesehatan Mental

2021, Vol. 6(1), 70-78

doi: 10.20473/jpkm.v6i12021.70-78

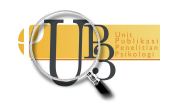


Selain meningkatnya persaingan di dunia kerja yang berdampak pada masalah pengangguran, pada abad ke-21 ini Indonesia juga dihadapkan pada perkembangan teknologi di revolusi industri 4.0. Perubahan teknologi dan globalisasi yang cepat hingga meningkatnya permintaan pelanggan, juga telah memaksa organisasi untuk mengadopsi struktur pekerjaan yang mendukung fleksibilitas dan kemampuan beradaptasi (Van Dam, 2004). Dengan adanya dorongan ekonomi tersebut, maka para pencari karyawan atau employers mencari generasi baru atau lulusan yang dapat dipekerjakan yang bukan hanya sekedar lulus dari disiplin ilmu tertentu, tetapi juga dapat dipekerjakan dan memiliki sikap serta perilaku yang baik dari universitas ataupun perguruan tinggi (Mabuza, 2012).

Dari beberapa uraian yang telah disebutkan diatas, maka penting bagi mahasiswa untuk menyiapkan diri sebaik mungkin agar dapat bersaing di dunia kerja dan memiliki kemampuan kerja yang dibutuhkan oleh perusahaan. Salah satu upaya yang bisa dilakukan yaitu dengan memiliki konsep employability bagi mahasiswa di perguruan tinggi. Universitas atau perguruan tinggi yang berfokus pada employability dapat memiliki mahasiswa yang berkualitas tinggi, menarik, serta memiliki keunggulan kompetitif di pasar global (Mattis, 2018).

Pada penelitian ini, penulis menggunakan konsep employability yang dilihat dari perspektif individu yang dikembangkan oleh Rothwell, Herbert, dan Rothwell (2008) dikarenakan penelitian ini berfokus pada bagaimana mahasiswa akhir memandang dirinya terhadap kemampuan yang dimiliki sehingga nantinya dapat bersaing di pasar tenaga kerja. Sebagai konsep yang dilihat dari perspektif individu, maka self-perceived employability didefinisikan sebagai persepsi individu terkait dengan kemampuan yang dimilikinya untuk dapat memperoleh pekerjaan yang tepat dan sesuai. Konsep self-perceived employability terbentuk berdasarkan empat komponen yang saling mempengaruhi satu sama lain yaitu keyakinan diri, kondisi pasar tenaga kerja, latar belakang ilmu yang dipelajari, dan universitas tempat individu belajar (Rothwell dkk., 2008).

Menurut Pool dan Sewell (2007), individu dapat memiliki employability apabila mampu melakukan pengembangan karir. Untuk menghadapi pengaturan dan pengembangan karir, Di Fabio (2014) mengembangkan konsep intrapreneurial self-capital (ISC) sebagai sumber daya individu dalam konteks psikologi karir dimana setiap individu dianggap sebagai kolabolator dalam suatu organisasi dimana ia bekerja (Di Fabio \& Van Esbroeck, 2016). Intrapreneurial self-capital berkaitan dengan sumber daya pribadi yang konstan dengan perubahan terus-menerus dan transisi yang ada dengan menciptakan solusi inovatif ketika menghadapi kendala yang ditimbulkan oleh lingkungan dan mengubah kendala tersebut sebagai suatu sumber daya (Di Fabio, 2014). Definisi dari intrapreneurial self-capital adalah evaluasi diri secara positif terhadap konsep diri yang ditandai dengan memiliki kemampuan untuk berkomitmen, mampu untuk mengidentifikasi tujuan, memiliki kendali terhadap peristiwa kehidupan, memiliki kemampuan untuk memecahkan masalah secara kreatif, mengembangkan keterampilan pribadi, mampu merubah kendala menjadi sumber daya dan mampu menerapkan keterampilan pengambilan keputusan pada setiap aspek kehidupan dengan rasional dan hati-hatiKonsep mengenai intrapreneurial self-capital (ISC) dibentuk berdasarkan gagasan karateristik intrapreneur. Secara spesifik, ISC merupakan atribut yang dimiliki oleh individu sebagai seorang intrapreneur dalam hidup mereka (Di Fabio, 2014). Menurut Savickas (2011, dalam Di Fabio, 2014) disebutkan bahwa inti dari intrapreneurial sangat berguna untuk mendesain masa depan pribadi, menciptakan peluang untuk diri sendiri, memperkuat keterampilan adaptasi, mempertahankan employability, dan secara proaktif menciptakan pengembangan bagi diri sendiri dan profesional (Di Fabio, 2014).

Selain konsep karir, Pool dan Sewell (2007) juga menyebutkan bahwa kecerdasan emosional dapat berdampak pada employability seseorang. Menurut Pool dan Sewell (2007), kecerdasan emosional dapat mendorong potensi seseorang untuk dapat dipekerjakan karena bagaimana seseorang dapat

INSAN Jurnal Psikologi dan Kesehatan Mental

2021, Vol. 6(1), 70-78

doi: 10.20473/jpkm.v6i12021.70-78

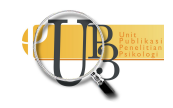


berinteraksi dengan orang lain adalah bagian penting dalam sebuah organisasi. Kecerdasan emosional dapat meningkatkan kemampuan untuk mempelajari kesadaran akan suasana hati (mood) dan secara efektif dapat mengatur emosi yang tertekan, serta kemampuan untuk mendengarkan dan berempati sehingga dalam perkembangannya dapat memperoleh kemampuan emosional tertentu sehingga menyebabkan kinerja yang maksimal di tempat kerja (Singh, 2015). Adapun konsep kecerdasan emosional itu sendiri terdiri dari tiga yaitu ability, trait, dan mixed (Petrides \& Furnham, 2015).

Dari ketiga konsep tersebut, penulis menggunakan konsep trait kecerdasan emosional kaerna sebelumnya penelitian yang dilakukan oleh Di Fabio (2014 dalam Keefer, Parker, \& Saklofske, 2018) untuk mengetahui persepsi mahasiswa di Italia untuk dapat dipekerjakan yang didasarkan pada kontribusi kecerdasan emosional sebagai trait dan ability. Hasilnya, diketahui bahwa kecerdasan emosional sebagai ability tidak berkontribusi secara signifikan terhadap perceived employability, sedangkan kecerdasan emosional sebagai trait memberikan kontribusi yang signifikan. Sehingga diketahui bahwa trait kecerdasan emosional secara keseluruhan memberikan dukungan yang kuat terhadap persepsi siswa mengenai karateristik pribadi yang membuat mereka dapat dipekerjakan (perceived employability) dalam pasar tenaga kerja saat ini (Keefer, dkk., 2018). Definisi dari trait kecerdasan emosional adalah kumpulan persepsi emosional yang terletak di level terendah dalam hirarki kepribadian, yang mana konstruk tersebut menyangkut persepsi diri mengenai kemampuan emosional yang dimiliki (Petrides, dkk., 2015).

Dari beberapa penjelasan yang telah diuraikan sebelumnya, maka penulis tertarik untuk melakukan penelitian ini dengan bertujuan untuk menguji secara empiris hubungan antara intrapreneurial selfcapital dan kecerdasan emosional terhadap self-perceived employability pada mahasiswa tingkat akhir. Sehingga muncul pertanyaan penelitian yaitu apakah terdapat hubungan antara intrapreneurial selfcapital dan kecerdasan emosional terhadap self-perceived employability pada mahasiswa tingkat akhir.

\section{Desain Penelitian}

\section{ME T O D E}

Penelitian ini dilakukan dengan metode kuantitatif dengan pengumpulan data melalui metode survei dan dengan tujuan penelitian eksplanatori, yaitu untuk menjelaskan mengapa suatu peristiwa terjadi, membangun, menguraikan, memperluas ataupun menguji teori (Neuman, 2014). Kemudian teknik pengambilan sampel pada penelitian ini yaitu teknik non-probability sampling yaitu accidental sampling yang didefinisikan sebagai teknik penentuan sampel berdasarkan kebetulan, yaitu siapa saja yang secara kebetulan bertemu dengan penulis serta dianggap cocok sebagai sumber data, maka orang tersebut dapat digunakan sebagai sampel penelitian (Sugiyono, 2009).

\section{Partisipan}

Partisipan dalam penelitian ini adalah mahasiswa tingkat akhir di perguruan tinggi di seluruh Indonesia dengan rentang usia 20-25 tahun dan termasuk dalam angkatan tahun 2012 hingga 2016. Jumlah keseluruhan partisipan sebanyak 327, dengan rincian partisipan dari program studi sarjana sebanyak 284 orang dan program studi diploma sebanyak 43 orang. Dari 327 partisipan, 25,7 persen adalah partisipan laki-laki dan 74,3 persen sisanya adalah partisipan perempuan. 


\section{Pengukuran}

Skala yang digunakan dalam penelitian ini berupa Intrapreneurial Self-Capital Scale (ISCS) oleh Di Fabio (2014) yang terdiri dari 28 butir dengan reliabilitas yang sangat baik $(\alpha=0,812)$, skala Trait Emotional Questionnaire Short-Form (TEIQue-SF) oleh Petrides (2009) yang terdiri dari 30 butir dengan reliabilitas yang sangat baik $(\alpha=0,874)$, dan Self-Perceived Employability Scale oleh Rothwell, dkk. (2008) yang terdiri dari 16 butir dengan reliabilitas yang sangat baik pula $(\alpha=0,801)$.

\section{Analisis Data}

Teknik analisis data yang digunakan dalam penelitian ini dengan menggunakan teknik analisis korelasi berganda. Dalam melakukan analisis tersebut, penulis menggunakan bantuan aplikasi IBM SPSS Statistics 22 for Windows.

\section{HAS IL PENELIT I A N}

Sebelum melakukan uji korelasi, penulis mengecek terlebih dahulu apakah asumsi parametrik dari variabel intrapreneurial self-capital $(M=100,83 ; S D=10,50 ; M i n=60$, Maks=131), kecerdasan emosional $(M=137,51 ; S D=19,14 ; \quad M i n=60$, Maks=195), dan self-perceived employability $(M=59,31 ; S D=8,36$; Min=19, Maks=80). Hasilnya, intrapreneurial self-capital (K-S-Z=0,058; $p=0,010$; Skewness=-0,37; Kurtosis=1,71), kecerdasan emosional (K-S-Z=0,035; $p=0,200$; Skewness $=-0,177$; Kurtosis $=0,988$ ), dan self-perceived employability (K-S-Z $=0,048 ; \quad p=0,067$; Skewness $=-0,317$; Kurtosis $=1,285$ ) dapat dikatakan berdistribusi normal.

Berdasarkan uji korelasi ganda yang dilakukan oleh penulis, diketahui bahwa korelasi antara intrapreneurial self-capital dengan self-perceived employability adalah cenderung positif dan sedang $(r(327)=0,348, p<0,001)$ sedangkan korelasi antara kecerdasan emosi dengan self-perceived employability juga cenderung sedang dan positif $(r(327)=0,344, p<0,001)$.

\section{I S K U S I}

Penelitian ini dilakukan untuk mengetahui hubungan antara intrapreneurial self-capital dan kecerdasan emosional terhadap self-perceived employability pada mahasiswa tingkat akhir. Pada analisis korelasi sederhana antara intrapreneurial self-capital dan self-perceived employability diketahui memiliki hubungan yang positif dan cenderung sedang. Individu yang memiliki intrapreneurial self-capital yang tinggi maka ia akan memiliki self-perceived employability yang tinggi pula. Hasil tersebut sesuai dengan penelitian sebelumnya yang dilakukan oleh Di Fabio (2014) bahwa intrapreneurial self-capital berkontribusi penting dalam persepsi kemampuan kerja (perceived employability). Individu yang mampu mengidentifikasi sumber daya intrapreneur maka akan lebih mampu menangani dan berhasil dalam perubahan yang terus-menerus di pasar tenaga kerja (Di Fabio, 2014). Hal tersebut dapat membantu seseorang untuk mengatasi realitas baru di dunia kerja, menjaga serta memelihara potensi dan bakat pribadi (Di Fabio \& Sakslosfe, 2019). Konsep intrapreneurial selfcapital mengacu pada individu yang memiliki intrapreneur. Individu yang memiliki sumber daya intrapreneur akan lebih mampu menangani dan berhasil dalam perubahan yang terus-menerus di pasar tenaga kerja (Di Fabio, 2014) . Menjadi individu yang intrapreneur berarti dapat bertindak sebagai inovator dan pemecahan masalah ide-ide di tempat kerja dan mengubah ide menjadi usaha yang menguntungkan untuk kepentingan organisasi sehingga seseorang yang memiliki intrapreneurial

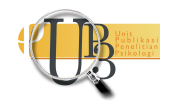


dapat mengembangkan dan menggunakannya secara efektif untuk meningkatkan employability dan mempercepat karir ke tingkat berikutnya.

Begitu pula hasil korelasi sederhana variabel kecerdasan emosional terhadap self-perceived employability menunjukkan temuan bahwa terdapat hubungan yang positif antar kedua variabel tersebut sehingga individu yang memiliki kecerdasan emosional yang tinggi maka ia akan memiliki self-perceived employability yang tinggi pula. Hasil penelitian tersebut sesuai dengan penelitian yang dilakukan oleh Di Fabio (2014) dalam Keefer, dkk. (2018) bahwa trait kecerdasan emosional secara keseluruhan memberikan dukungan yang kuat terhadap persepsi siswa mengenai karateristik pribadi yang membuat mereka dapat dipekerjakan (perceived employability) dalam pasar tenaga kerja saat ini (Keefer, dkk., 2018). Hasil penelitian yang dilakukan oleh Udayar, dkk. (2018) juga menunjukkan bahwa individu dengan trait kecerdasan emosional yang tinggi maka secara tidak langsung dapat mengaktivasi sumber daya adaptasi karir yang menunjukkan self-perceived employability yang lebih baik.

Penelitian yang dilakukan oleh Di Fabio dan Saklosfe (2019) menyatakan bahwa keterkaitan yang berkelanjutan antara intrapreneurial self-capital dan kecerdasan emosional akan menambah dukungan terhadap pentingnya mengembangkan kedua karateristik tersebut dalam kaitannya dengan pekerjaan tertentu. Hasil dari studi tersebut juga diketahui bahwa antar kedua variabel dapat memiliki implikasi untuk meningkatkan sumber daya yang dibutuhkan oleh mahasiswa dalam menghadapi tantangan dan transisi yang telah menjadi inti dari pekerjaan (Di Fabio \& Saklosfe, 2018). Hal tersebut juga sesuai dengan hasil dari penelitian ini bahwa kedua variabel tersebut memiliki hubungan dengan self-perceived employability sehingga ketika individu memiliki evaluasi diri yang positif terhadap atribut dan konsep diri yang didukung dengan kemampuan untuk mempersepsikan dan memahami emosi maka secara tidak langsung dapat menimbulkan persepsi individu terhadap dirinya untuk dapat dipekerjakan.

\section{S I M P U L A N}

Berdasarkan rumusan masalah dan analisis data yang telah dilakukan dalam penelitian ini, maka dapat disimpulkan bahwa ada hubungan antara intrapreneurial self-capital dan kecerdasan emosional terhadap self-perceived employability. Sejalan dengan hasil penelitian yang diperoleh, maka penulis mengajukan beberapa saran, yaitu; (1) bagi penelitian selanjutnya, disarankan untuk melakukan uji pengaruh pada variabel-variabel tersebut dan juga meneliti variabel-variabel lain untuk menambah variasi penelitian terkait dengan self-perceived employability seperti career self management, cultural competence, self efficacy, career resilience, sociability, entrepreneurial orientation dan proactivity (Bezuidenhout, 2011; Coetzee \& Potgieter, 2013); (2) bagi mahasiswa tingkat akhir, hendaknya meningkatkan aspek intrapreneurial self-capital dan kecerdasan emosional apabila ingin meningkatkan kemampuan diri untuk dapat dipekerjakan (self-perceived employability); (3) bagi perguruan tinggi, disarankan untuk membantu mengembangkan keterampilan mahasiswanya dengan menyediakan pelatihan-pelatihan dan program-program yang dapat membentuk aspek-aspek yang dapat bepengaruh terhadap employability.

\section{UCA PA N T ERIMA KASIH}

Penulis mengucapkan terima kasih pada seluruh responden yang terlibat secara sukarela dalam penelitian ini dan juga pihak-pihak lain yang turut membantu proses penyesuaian alat ukur penelitian sebagai rater sehingga penelitian ini dapat terselesaikan dengan baik.

INSAN Jurnal Psikologi dan Kesehatan Mental

2021, Vol. 6(1), 70-78

doi: 10.20473/jpkm.v6i12021.70-78 


\section{DEKLARASI POTENSI TERJADINYA KONFLIK KEPENTINGAN}

Fiqi Hariya Afshida dan Cholichul Hadi tidak bekerja, menjadi konsultan, memiliki saham, atau menerima dana dari perusahaan atau organisasi mana pun yang akan mengambil untung dari naskah ini, dan telah mengungkapkan bahwa ia tidak memiliki afiliasi selain yang telah disebut di atas.

\section{PUSTAKA ACUAN}

Agustinus, M. (2017, April 27). Ada 3,98 Juta Perusahaan Baru di RI dalam 10 Tahun Terakhir. Diakses dari https://finance.detik.com/berita-ekonomi-bisnis/d-3485474/ada-398-juta-perusahaanbaru-di-ri-dalam-10-tahun-terakhir

Badan Pusat Statistik. (2018, Februari 7). Keadaan Ketenagakerjaan Indonesia Februari 2018. Diakses dari https://www.bps.go.id/publication/2018/06/04/b7e6cd40aaea02bb6d89a828/keadaanangkatan-kerja-di-indonesia-februari-2018.html

Bezuidenhout, M. (2011). The development and evaluation of a measure of graduate employability in the new world of work. Tesis. Pretoria: University of Pretoria.

Coetzee, M. (2012). A framework for developing student graduateness and employability in the economic and management sciences at the University of South Africa. Developing student graduateness and employability: Issues, provocations, theory and practical guidelines, 119-152. Ranburg: Knowres Publishing.

Di Fabio, A. (2014). Intrapreneurial self-capital: A new construct for the 21st century. Journal of Employment Counseling, 51(3), 98-111.

Di Fabio, A., \& Van Esbroeck, R.(2016). Intrapreneurial Self-Capital: A concept fitting a life-designing intervention Intrapreneurial Self-Capital: A concept fitting a life-designing intervention. Trento TN: Edizioni Centro Studi Erickson.

Di Fabio, A., \& Saklofske, D. H. (2019). The contributions of personality traits and emotional intelligence to intrapreneurial self-capital: Key resources for sustainability and sustainable development. Sustainability, 11(5), 1240.

Gewati, M. (2016, April 23). Kenapa Lulusan Perguruan Tinggi Makin Susah Mendapatkan Pekerjaan? Diakses

dari https://edukasi.kompas.com/read/2016/04/23/17424071/Kenapa.Lulusan.Perguruan.Tinggi. Makin.Susah.Mendapat.Pekerjaan.?page=all

Gewati, M. (2018, September 06). Sarjana Melimpah, tapi Perusahaan Sulit Dapat Tenaga Siap Pakai. Diakses dari https://edukasi.kompas.com/read/2018/09/06/13140861/sarjana-melimpahtapi-perusahaan-sulit-dapat-tenaga-kerja-siap-pakai

Indriani. (2018, Juni 30). Tiap Tahun Ratusan Ribu Sarjana Menganggur. Diakses dari https://www.liputan6.com/health/read/3574285/tiap-tahun-ratusan-ribu-sarjanamenganggur

Iredale, R., Toner, P., Turpin, T., \& Esquinas, M. F. (2015). A Report on the APEC Region Labour Market: Evidence of Skills Shortages and General Trends in Employment and The Value of Better Labour Market Information Systems. Sydney: Asia-Pacific Economic Cooperation Secretariat.

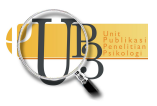


Keefer, K. V., Parker, J. D., \& Saklofske, D. H. (2018). Emotional Intellifence in Education: Integrating Research with Practice. Cham: Springer International Publishing AG.

Kevin, A. (2019, Maret 17). Disebut Pemerintah Rendah, Pengangguran RI Tertinggi di ASEAN. Diakses dari https://www.cnbcindonesia.com/news/20190317185220-4-61119/disebut-pemerintahrendah-pengangguran-ri-tertinggi-di-asean

Mabuza, L. O. K. (2012). Towards improved youth employability. Dalam M. Coetzee, JA. Botha, N. Eccles, H. Nienaber \& N. Holzhausen (Ed). Developing Student Graduateness and Employability, 153-166. Randburg: Knowes Publishing.

Mattis, G. (2018, Oktober 16). The Importance of Graduate Employability for Universities. Diakses dari https://www.qs.com/the-importance-of-graduate-employability-for-universities/

Neuman, W. L. (2014). Social Research Methods: Qualitative and Quantitative Approaches Seventh Edition. London: Pearson Education Limited.

Newbury, P. (2016). How Intrapreneurship Can Fast-track Your Career. Diakses dari https://social.usq.edu.au/career/blogs/intrapreneurship-fast-track-your-career-paul

Pallant, J. (2010). SPSS Survival Manual 4th Edition. Sydney: Allen \& Uwin.

Petrides, K. V. (2009). Psychometric Properties of the Trait Emotional Intelligence Questionnaire (TEIQue). Dalam C. Stough, D. H. Saklofske, \& J. D. Parker (Ed). Assessing Emotional Intelligence: Theory, Research, and Applications, 85-102. London: Springer.

Petrides, K. V., \& Furnham, A. (2001). Trait emotional intelligence: Psychometric investigation with reference to established trait taxonomies. European journal of personality, 15(6), 425-448.

Petrides, K. V., Siegling, A. B., \& Saklofske, D. H. (2016). Theory and measurement of trait emotional intelligence. The Wiley handbook of personality assessment, 90-103. New Jersey: John Wiley \& Sons.

Pool, L. D., \& Sewell, P. (2007). The key to employability: developing a practical model of graduate employability. Education+ Training, 49(4), 277-289.

Potgieter, I., \& Coetzee, M. (2013). Employability attributes and personality preferences of postgraduate business management students. SA Journal of Industrial Psychology, 39(1), 1-10.

Raharjo, E. (2017, September 12). Menaker: Sarjana Keluaran Kampus Indonesia Tak Langsung Siap Pakai. Diakses dari https://news.detik.com/berita-jawa-tengah/d-3640184/menaker-sarjanakeluaran-kampus-indonesia-tak-langsung-siap-pakai

Rothwell, A., Herbert, I., \& Rothwell, F. (2008). Self-perceived employability: Construction and initial validation of a scale for university students. Journal of vocational behavior, 73(1), 1-12.

Singh, D. (2015). Emotional Intelligence at Work: A Professional Guide-Fourth Revised Edition. New Delhi: SAGE Publications.

Sugiyono. (2009). Metode Penelitian Kuantitatif Kualitatif dan R\&D . Bandung: Alfabeta.

Udayar, S., Fiori, M., Thalmayer, A. G., \& Rossier, J. (2018). Investigating the link between trait emotional intelligence, career indecision, and self-perceived employability: The role of career adaptability. Personality and Individual Differences, 135, 7-12.

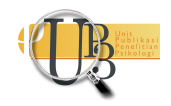


Van Dam, K. (2004). Antecedents and consequences of employability orientation. European Journal of work and organizational Psychology, 13(1), 29-51. 